\title{
Research capacity development in podiatry: the contribution of the Society of Chiropodists and Podiatrists
}

\author{
Jackie Campbell
}

From Society of Chiropodists and Podiatrists Annual Conference 2010

Bournemouth, UK. 21-23 October 2010

\section{Objectives and relationship to conference themes} The development of a research culture within the Society of Chiropodists and Podiatrists, and the research capacity building within the profession that must underpin this, is an essential element of both the 'learn' and 'achieve' themes of the conference.

The role of professional bodies in developing professional practice and the maintenance of standards is unquestioned and is the main focus for the work of these bodies. However, research evidence is required to provide the evidence base for that professional practice. This need for evidence is becoming more urgent as, for example, funders of health-care services and fee-paying patients are increasingly requiring evidence of efficacy and effectiveness of interventions. In the UK, the move to commissioning of services for the National Health Service is accelerating this trend.

Professional bodies should therefore have a role in developing that evidence base as a core part of their business. However, particularly for the smaller allied health professions, scarce resources and other competing priorities mitigate against this. This poster will look at how the Society of Chiropodists and Podiatrists have begun to tackle this problem and will illustrate how, in less than five years, they have moved from research being a special interest of a few, to it being a core part of the organisation, with major successes for podiatrists in prestigious, competitive national research schemes.

\section{Relevance and impact of this topic}

An evidence base for the profession is essential if it is to survive. This poster describes how that evidence base is

Society of Chiropodists and Podiatrists, London, UK being encouraged and developed within the professional body.

\section{Participant outcomes}

Participants will gain an understanding and appreciation of the role of professional bodies in general, and the UK Society of Chiropodists and Podiatrists in particular, in developing the capacity to provide the evidence base for the profession.

Published: 20 December 2010

doi:10.1186/1757-1146-3-S1-P3

Cite this article as: Campbell: Research capacity development in podiatry: the contribution of the Society of Chiropodists and Podiatrists. Journal of Foot and Ankle Research 2010 3(Suppl 1):P3.

Submit your next manuscript to BioMed Central and take full advantage of:

- Convenient online submission

- Thorough peer review

- No space constraints or color figure charges

- Immediate publication on acceptance

- Inclusion in PubMed, CAS, Scopus and Google Scholar

- Research which is freely available for redistribution 